\title{
SECURITY ASPECTS OF WASTE DISPOSAL
}

\author{
Vladimir Tomašević ${ }^{1}$ (i) \\ Mubarak Saeed Ahmed Burshaid Al Dhaheri \\ Tatjana Ilić-Kosanović ${ }^{3}$ (D)
}

DOI: https://doi.org/10.31410/LIMEN.S.P.2019.121

\begin{abstract}
Waste disposal is one of the main issues of today's world in terms of environmental protection, sustainable development and economic growth. One of the less researched subjects is the security aspect of waste disposal and management. This topic includes environmental, political, and economic aspects. This paper examines the approaches to waste disposal in regard of hazardous waste management and disposal, nuclear waste management and disposal, etc. and their impact on complex issues of national, regional, and global security, and possible conflict generation. The paper includes the analysis of the interviews with security and waste management experts in the Republic of Serbia and United Arab Emirates and presents a model for the approach to waste management and disposal that includes the security aspect.
\end{abstract}

Keywords: Waste management, the Republic of Serbia, United Arab Emirates.

\section{INTRODUCTION}

$\mathrm{D}^{\prime}$ uring the last two decades, the question of waste disposal and its consequences on economy and environment is starting to be in the focus of academic and professional researchers, as well as governmental agencies and private companies. Nevertheless, one of the aspects of waste disposal is often neglected; it is the security aspect (Fischhendler, Katz \& Feitelson, 2016) that encompasses environmental, economic, and political aspects, too.

Even though there is not enough research, existing studies on this topic have included the issues of solid waste management (Bezergianni, Dimitriadis, Faussone \& Karonis, 2017), medical waste management (Awodele, Adewoye, \& Oparah, 2016), disaster management (Mohnkern, 2019), various hazardous waste management (Gómez-Delgado \& Tarantola, 2006), cross-border security (Fischhendler, Katz \& Feitelson, 2016; Happ \& Bruns, 2017), E-waste (Mitra \& Mitra, 2018), nuclear waste management (Kermisch, 2016), water and water infrastructure security (Ostfeld \& Salomons, 2004; Baer \& Gerlak, 2015), and even military forces security management regarding the waste management (Bosetti \& Bridges, 2009).

This paper aims to examine the approaches to waste disposal in regard of hazardous waste management and disposal, nuclear waste management and disposal, etc. and their impact on complex issues of national, regional, and global security, and possible conflict generation. The paper includes the analysis of the interviews with security and waste management experts in the Republic of Serbia and United Arab Emirates and presents a model for the approach to waste management and disposal that includes the security aspect.

$1 \quad$ University “Union - Nikola Tesla”, School of Engineering Management, Bulevar vojvode Mišića 43, 11000 Belgrade, Serbia

2 University "Union - Nikola Tesla", School of Engineering Management, Bulevar vojvode Mišića 43, 11000 Belgrade, Serbia

3 University "Union - Nikola Tesla", School of Engineering Management, Bulevar vojvode Mišića 43, 11000 Belgrade, Serbia 


\section{SECURITY ASPECTS OF WASTE DISPOSAL - LITERATURE REVIEW}

Environmental security and national security are recognized by many countries during the last thirty years, one of the first countries that included environmental issues in national security was US in 1991 (Funke, 2011). European Union defines the waste as "any substance or object which holder (manufacturer) gets rid of, intends to get rid of or to which he is required to get rid of" (Nowacki, 2020). Organization for Security and Cooperation in Europe for the beginning of $21^{\text {st }}$ century has put more focus on the issues of environmental security, stability of the countries and the possibilities of conflict generation (OEBS, 2015). Inadequate waste disposal and management can cause not only a threat to human health but generate social and political conflicts on both inter-national and intra-national levels.

\subsection{Solid waste management}

Solid waste also lately plays significant role in security strategies because some types of waste like plastic waste, which comprises from 10 to 12 per cent of solid waste (Bezergianni, Dimitriadis, Faussone \& Karonis, 2017), can cause chemical accidents in case of fire, etc. Solid waste dumping sites cause major concern in certain parts of Russia for example (Sverdyukov, 2014), and illegal dumping sites are concerned as main issue in African countries (Fazzo, Minichilli, Santoro, Ceccarini, Della Seta, Bianchi, Comba \& Martuzzi, 2017). Even in developed countries, there is a question of security risks of solid waste dumps on the urban areas in their vicinity (Fazzo et al. 2017). Some of the countries that have heavy industry close to densely populated areas, such as Israel, tend to give more focus on regulation that provides complying with the higher waste management standards, nevertheless due to geographical and political problems, wider cooperation is often impossible (Alleson, Levin, Brenner \& Al Hmaidi, 2013).

\subsection{Hazardous waste disposal}

World Health Organization treats hazardous waste and its disposal as one of top environmental issues (Fazzo et al. 2017). Hazardous waste has many definitions and one of the most applicable is the one from the US Environmental Protection Agency that states the following:

Simply defined, a hazardous waste is a waste with properties that make it dangerous or $\mathrm{c} \mathrm{a}$ pable of having a harmful effect on human health or the environment. Hazardous waste is generated from many sources, ranging from industrial manufacturing process wastes to batteries and may come in many forms, including liquids, solids gases, and sludges. (n.d.).

Hazardous waste is differentiated from other solid waste as the one that contains substances or has characteristics that might make it harmful to human health or the environment. Hazardous waste includes the waste that derives from standard production processes (various solvents), the wastes deriving from petroleum refineries and pesticide industries, wastewaters, various sludges, discarded or not used chemical products, mercury containing products, etc. In many countries, especially in Asia, there is a growing concern over illegal hazardous waste disposal sites, where also many criminal activities (money laundering, hazardous waste smuggling, etc.) are connected to hazardous waste illegal disposal (White, 2016).

Hazardous and non-hazardous waste is prone to accidents and there are professional and scientific efforts to develop secure techniques of waste identification and treatment in the potential accidents or disaster scenarios (Kiss Leizer \& Tokody, 2017). 


\subsection{Nuclear waste disposal}

Nuclear waste can be considered as a type of hazardous waste. Nuclear disasters in Chernobyl in 1986 and Fukushima in 2011 have also raised the concern on the impact of nuclear waste on human health and environment. The greatest security concerns are storing used nuclear fuel and possibilities of use of weapon grade plutonium (Taebi \& Kloosterman, 2008). One of the issues in the focus of scientists is the strategic security aspect of short term and long-term possible incidents in regard to nuclear waste disposal (Kermisch, 2016).

\subsection{Medical waste disposal}

During the last decade, there is increased awareness of the problems associated with medical waste disposal (Awodele, Adewoye, \& Oparah, 2016), and the initiatives and programs for safe medical waste disposal, because of serious consequences on public health in case of inadequate medical waste disposal and treatment.

\subsection{E-waste disposal}

During the last decade e-waste is the highest rising type of waste (Martin \& Harris, 2017). E-waste often comprises of various hazardous materials: lead, mercury, chromium, same as different chemicals in plastic parts. Asian countries are especially threatened by the growing amount of e-waste and illegal e-waste disposal and illegal "recycling" (Cui, 2013; White, 2016; Fazzo et al. 2017) that cause major security risks. Nevertheless, this is more complex issue, because many poor countries actually serve as e-waste dumping ground for developed countries like USA and Japan (Monika, 2010).

\subsection{Wastewater}

Netherlands, for example, face the problem of wastewater disposal, amid the climate changes effects and increasing risk of floods (Markus, \& Savini, 2016). The example of situation on Palestinian-Israeli border shows the challenges of wastewater disposal as a major security issue, because water resources have long been in the focus of security strategists, but the disposal and treatment of wastewater hasn't (Alleson, Levin, Brenner \& Al Hmaidi, 2013; Fischhendler, Katz \& Feitelson, 2016). This issue is important also in the countries prone to natural disasters like earthquakes such are New Zealand, California in the US, British Columbia in Canada, etc. (Mohnkern, 2019). The issue of precedence of security over sustainability remains one of the open questions for scientists, politicians, and the inhabitants of the volatile areas alike (Fischhendler, Katz \& Feitelson, 2016).

\subsection{Cross-border cooperation}

Some of the issues of waste disposal and management are often settled in the programs of cross border cooperation, like the issues between Ukraine and Belarus that are collaborate through EU funded programs. But even those programs are influenced by different policies of waste categorizations, as they are in both countries inherited form Soviet times and EU proposes new classification, policies and procedures (Happ \& Bruns, 2017). Waste management (Alleson, Levin, Brenner \& Al Hmaidi, 2013) initiatives exist in conflict prone regions, but the implementation of those initiatives, especially in the long-term basis remains one of the, currently, often unsolvable problems. 


\section{MATERIALS AND METHODS}

\subsection{Objectives and survey design}

The objective of the empirical part of the research is to examine the approach to waste management in the Republic of Serbia and United Arab Emirates, as countries with different geographical location and economic development status. The series of interviews has been organized in Belgrade, Serbia and Dubai, United Arab Emirates from September 16, to November 8, 2019 through in-person and online structured interviews. The participants have been chosen from academics in the fields of security, law, economics, environmental studies, disaster management, and waste management, same as the professionals from the matching areas. The academics and experts have been given one open question regarding security aspects of waste management, to identify main security problems regarding the waste disposal in their respective countries and overall.

\subsection{Description of the sample}

Eighteen academics and experts in the fields of security, law, economics, environmental studies or protection, disaster management, and waste management have been interviewed, eleven from Serbia and seven from United Arab Emirates. From Serbia, the participants have included: one academic from interdisciplinary field (security, economics, and environmental engineering), two academics from the field of security studies, one from the field of economics and one form environmental studies. Experts from Serbia have included: two security experts, one environmental expert, one waste management expert, one disaster management expert, and one expert from the legal field. The interviewees from United Arab Emirates have included three academics from the field of security studies, one from the legal field, two experts from waste management studies and one environmental expert. Demographical profile of the participants is given at Table 1.

Table 1. Demographic variables

\begin{tabular}{|l|l|l|c|}
\hline Code Name & Country & Position & Experience (years) \\
\hline P1 & Serbia & Security expert & $>20$ \\
\hline P2 & Serbia & Environmental expert & $11-15$ \\
\hline P3 & Serbia & Academic (security) & $<5$ \\
\hline P4 & Serbia & Academic (economics) & $11-15$ \\
\hline P5 & Serbia & Academic (environment) & $6-10$ \\
\hline P6 & Serbia & Security expert & $6-10$ \\
\hline P7 & Serbia & Disaster management expert & $11-15$ \\
\hline P8 & Serbia & Waste management expert & $11-15$ \\
\hline P9 & Serbia & Academic (interdisciplinary) & $11-15$ \\
\hline P10 & UAE & Academic (security) & $6-10$ \\
\hline P11 & UAE & Academic (security) & $11-15$ \\
\hline P12 & UAE & Academic (security) & $>20$ \\
\hline P13 & UAE & Expert (waste management) & $>20$ \\
\hline P14 & UAE & Environmental expert & $11-15$ \\
\hline P15 & UAE & Expert (waste management) & $11-15$ \\
\hline P16 & UAE & Academic (law) & $11-15$ \\
\hline P17 & Serbia & Academic (engineering management) & $6-10$ \\
\hline P18 & Serbia & Expert (law) & $11-15$ \\
\hline
\end{tabular}




\section{RESULTS AND DISCUSSION}

Academic researchers and experts from Serbia (P1, P3, P9, and P18) agreed that the current regulative is mostly in lieu with European Union laws; nevertheless, they noted the implementation of existing laws regarding waste management as a crucial problem for the future security strategies that would include environmental aspects. Environmental researchers and experts from both countries emphasise the lack of education as the key threat for implementing future waste management programs same as political frictions on national, regional and international levels.

Academics and experts in Serbia (P17, P6, and P2) noted the necessity for understanding the role of emerging new technologies in identifying waste disposal problems (illegal waste sites, etc.) in developing countries. One academic (P17) suggested the great potential of using drones to identify illegal waste disposal sites. The participants form UAE (P10, P11, P12, and P12) emphasised that in UAE new technological solutions are already implemented, but that there is not enough awareness of the security threats that e-waste and, especially hazardous waste pose to the countries and regions and the possibilities of conflict generation in the future regarding the water safety and provision for all.

Academics and experts from UAE (P10, P13, P14, and P15) have stated the success of the programs implemented in order to reach the goal of reducing the quantity of waste discarded into landfills to zero and converting solid waste into energy by using innovations and new technologies that can be implemented not only in various countries with similar economic development and similar geography, but in many developing countries too.

Academics from both countries (P3, P4, P5, P10, P11, and P12) emphasized the importance of using academics' and experts' opinions based on robust research in developing any waste disposal strategies in regard to security aspect. Also, academics and experts (P1, P2, P7, P8, P13, $\mathrm{P} 14$, and P15) from both countries, agreed on the financial concerns that may cause a serious problem, especially for developing countries, as many of the potential waste management programs require vast financial funds that are unattainable for developing countries.

Table 2. Major waste disposal concerns

\begin{tabular}{|l|l|}
\hline Regulative implementation & Financial support \\
\hline Illegal dumping sites & Non usage of experts' opinions \\
\hline Education of citizens & Not enough awareness se of the new technologies impact \\
\hline Hazardous waste accumulation & E-waste accumulation \\
\hline
\end{tabular}

Source: Authors based on interviews

Based on the results of the interviews, the authors propose a model for waste disposal management that can be implemented in developed countries such as United Arab Emirates, and developing countries such as Serbia.

The first action is developing waste management procedures that would derive from existent and future regulative (which could be called as Action zero) on national and international level that would tackle waste disposal issues in terms of various kinds of waste. The second step would be developing of waste management procedures based on national and international legislation that would be developed on the level of local communities, companies, and other organizations. The third stage would be education of public servants, companies, various organizations, and 
entire population, especially youth on the importance on developing waste management programs that will ensure future generations with the foundation of the waste management system that takes into the account security issues. This activity needs to be implemented with serious effort in order to avoid popular trends not based on scientific results and to keep away from any political bias.

The fourth segment would be implementation of security policies and procedures in regard of environmental security that would provide for national, regional and international security and monitoring of those policies by academic and professional experts in the field in order to propose potential corrective steps. Almost simultaneously, the cooperation phase would insure exchange the data and successful examples between the countries with similar geographical and economic situation and developing of joint waste management ventures. And the last phase would be the evaluation of the whole process in order to develop potential new legislation and policies, same as educational programs.

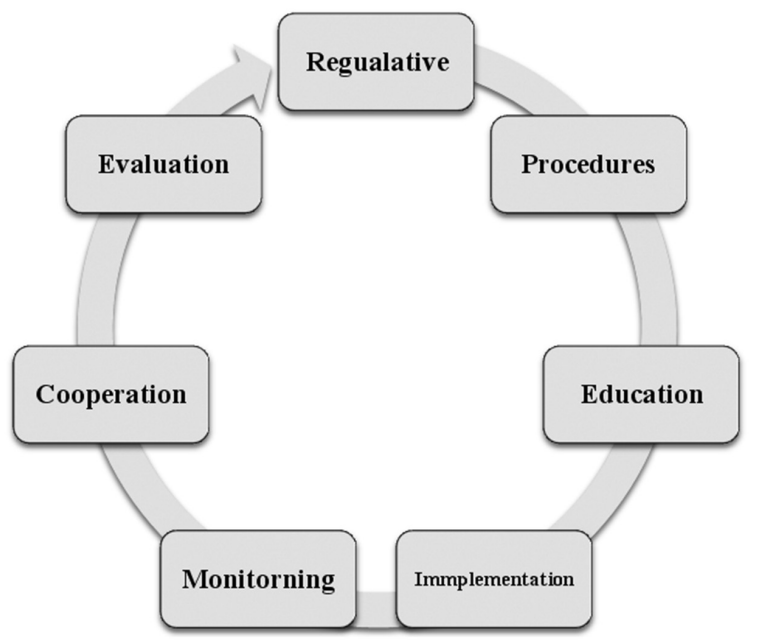

Figure 1. Proposed model of waste management cycle

Source: Authors

\section{FUTURE RESEARCH DIRECTIONS}

This study has limitations in terms of methodology and scope of data. For the future research ore extensive research could include specific issues, in depth surveys and using statistical methods in analysing collected data from various countries.

\section{CONCLUSION}

This paper examined literature on the approaches to waste disposal in regard of hazardous waste management and disposal, nuclear waste management and disposal, etc. and their impact on complex issues of national, regional, and global security, and possible conflict generation. The paper has included analysis of the interviews with security and waste management experts in the Republic of Serbia and United Arab Emirates and presented a model for the approach to waste management and disposal that includes the security aspect. This model encompasses regulative and its implementation, education, monitoring of activities, with the emphasis on intersectional and regional and wider cooperation, same as the evaluation of the whole cycle and corrective steps. 


\section{REFERENCES}

Alleson, I., Levin, J., Brenner S., \& Al Hmaidi, M. S. (2013). Peace and Pollution: An Examination of Palestinian-Israeli Trans-Boundary Hazardous Waste Management 20 Years after the Oslo Peace Accords, Journal of Peacebuilding \& Development, 8:1, 15-29, DOI: $10.1080 / 15423166.2013 .785651$

Awodele, O., Adewoye, A. A., \& Oparah, A. C. (2016). Assessment of medical waste management in seven hospitals in Lagos, Nigeria. BMC Public Health, 16(1), 1-11. https://doi. org/10.1186/s12889-016-2916-1

Baer, M., \& Gerlak, A. (2015). Implementing the human right to water and sanitation: a study of global and local discourses. Third World Quarterly, 36(8), 1527-1545. https://doi.org/10 $.1080 / 01436597.2015 .1043993$

Bezergianni, S., Dimitriadis, A., Faussone, G.-C., \& Karonis, D. (2017). Alternative Diesel from Waste Plastics. Energies (19961073), 10(11), 1750. https://doi.org/10.3390/en10111750

Bosetti, T., \& Bridges, D. (2009). The Unit Field Sanitation Team: A Square Peg in a Round Hole. U.S. Army Medical Department Journal, 31-33. Retrieved from http://search.ebscohost.com/login.aspx?direct $=$ true $\& \mathrm{db}=\mathrm{a} 9 \mathrm{~h} \& \mathrm{AN}=43823365 \&$ site $=$ ehost-live

Cui, S. (2013). Beyond History: non-traditional security cooperation and the construction of Northeast Asian international society. Journal of Contemporary China, 22(83), 868-886. https://doi.org/10.1080/10670564.2013.782131

Fazzo, L., Minichilli, F., Santoro, M., Ceccarini, A., Della Seta, M., Bianchi, F., Comba, P., \& Martuzzi, M. (2017). Hazardous waste and health impact: a systematic review of the scientific literature. Environmental Health: A Global Access Science Source, 16, 1-11. https:// doi.org/10.1186/s12940-017-0311-8

Fischhendler, I., Katz, D., \& Feitelson, E. (2016). Identifying synergies and trade-offs in the sustainability-security nexus: the case of the Israeli-Palestinian wastewater treatment regime. Hydrological Sciences Journal/Journal Des Sciences Hydrologiques, 61(7), 13581369. https://doi.org/10.1080/02626667.2014.993644

Funke, O. (2011). The role of biopolitics in environmental security analysis. Politics \& the Life Sciences, 30(1), 71-76. https://doi.org/10.1017/S073093840001772X

Gómez-Delgado, M., \& Tarantola, S. (2006). GLOBAL sensitivity analysis, GIS and multi-criteria evaluation for a sustainable planning of a hazardous waste disposal site in Spain. International Journal of Geographical Information Science, 20(4), 449-466. https://doi. org/10.1080/13658810600607709

Happ, D., \& Bruns, B. (2017). The EU and Its "Ring of Friends"-Eye-level or Top-down Relationships? Problems of Post-Communism, 64(2), 94-105. https://doi.org/10.1080/107582 16.2016.1176863

Kermisch, C. (2016). Specifying the Concept of Future Generations for Addressing Issues Related to High-Level Radioactive Waste. Science \& Engineering Ethics, 22(6), 1797-1811. https://doi.org/10.1007/s11948-015-9741-2

Kiss Leizer, G. K., \& Tokody, D. (2017). Radiofrequency Identification by Using Drones in Railway Accidents and Disaster Situations. Interdisciplinary Description of Complex Systems, 15(2), 114-132. https://doi.org/10.7906/indecs.15.2.1

Markus, M., \& Savini, F. (2016). The implementation deficits of adaptation and mitigation: green buildings and water security in Amsterdam and Boston. Planning Theory \& Practice, 17(4), 497-515. https://doi.org/10.1080/14649357.2016.1210666 
Martin, K. B., \& Harris, C. (2017). An Analysis of E-waste: When Do Electronics Die? Journal of the Indiana Academy of the Social Sciences, 17(1), 16-24. Retrieved from http://search. ebscohost.com/login.aspx?direct $=$ true $\& \mathrm{db}=\mathrm{a} 9 \mathrm{~h} \& \mathrm{AN}=129365579 \&$ site $=$ ehost-live

Mitra, S., \& Mitra, J. C. (2018). Issues of Electronic Waste on Life - A Reality. Scholedge International Journal of Multidisciplinary \& Allied Studies, 5(11), 112-121. Retrieved from http://search.ebscohost.com/login.aspx?direct=true \&db=a9h\&AN=136473509\&site=ehost-live

Mohnkern, S. (2019). Recommendations for Catastrophic Wastewater System Failures in a Modern Metropolitan Area. Journal of Environmental Health, 82(2), 14-16. Retrieved from http://search.ebscohost.com/login.aspx?direct=true \&db=a9h\&AN=138071692\&site=ehost-live

Monika, J. K. (2010). E-Waste Management: As a Challenge to Public Health in India. Indian Journal of Community Medicine, 35(3), 382-385. https://doi.org/10.4103/0970-0218.6925

Nowacki, K. (2020). Environmentally Responsible Policy of Wastes in Steel Industry. Metalurgija, 59(1), 77-80.

OEBS. (2015). OEBS i savremeni bezbednosni izazovi. Zbirka eseja. Organizacija za evropsku bezbednost i saradnju. Misija u Srbiji. Beograd.

Ostfeld, A., \& Salomons, E. (2004). Optimal Layout of Early Warning Detection Stations for Water Distribution Systems Security. Journal of Water Resources Planning \& Management, 130(5), 377-385. https://doi.org/10.1061/(ASCE)0733-9496(2004)130:5(377)

Rettig, E. (2016). Limits to cooperation: why Israel does not want to become a member of the International Energy Agency. Israel Affairs, 22(2), 512-527. https://doi.org/10.1080/13537 121.2016.1140357

Sverdyukov, N. (2014). The improvement of law enforcement activities in the field of environmental security in Russia. Vestnik IKBFU, (3), 155-161. Retrieved from http://search. ebscohost.com/login.aspx?direct $=$ true $\& \mathrm{db}=\mathrm{a} 9 \mathrm{~h} \& \mathrm{AN}=95780327 \&$ site $=$ ehost-live

Taebi, B., \& Kloosterman, J. L. (2008). To Recycle or Not to Recycle? An Intergenerational Approach to Nuclear Fuel Cycles. Science \& Engineering Ethics, 14(2), 177-200. https:// doi.org/10.1007/s11948-007-9049-y

United States Environmental Agency. (n.d.). What is a Hazardous Waste? Retrieved November 11, 2019 from https://www.epa.gov/hw/learn-basics-hazardous-waste

White, R. (2016). Building NESTs to combat environmental crime networks. Trends in Organized Crime, 19(1), 88-105. https://doi.org/10.1007/s12117-015-9261-0 